\title{
Decoding the Undecoded: Sexist Ideology \\ in Sherry Argov's Why Men Love Bitches?
}

\begin{abstract}
This paper explores the various strategies of sexism employed by Sherry Argov, the author of the best- selling narrative "Why men love bitches?": From Doormat to Dream girl- A Woman's Guide to Holding Her Own in a Relationship, that was sold and published across the globe in more than thirty languages. The book schools women on ways to succeed in their relationship with men. It appears to empower women to be in control of their lives. The writer employs the term "Bitch" throughout the whole book as an ideal positive symbol of strength that all females should strive to be like. The study aims to analyze the language used to address, describe and guide women. It hypothesizes that women are devalued and negatively represented. The language used is not as it seems to be to authorize women but rather
\end{abstract}

Marwa Abd El Azim

Assistant Professor, Misr University for

Science and Technology (MUST), Egypt

to degrade and humiliate them. It investigates the semantic, lexical and rhetorical strategies that are utilized in the narrative to underpin the hidden ideology. For the data analysis, the paper follows an eclectic approach that applies the theories of Mills' model of sexism (2008), Feminist Critical discourse analysis developed by Lazar (2005) and the connotations of words and presupposition as introduced by Yule (1996). The study reveals some conclusions that validate the hypotheses. It shows that writers can intentionally choose words of their choice that carry covert meanings to impact readers' perception. Women should pay more attention to word choices rather than simply accepting what is written as it is.

Keywords: Sexism, Sherry Argov, Feminist Critical Discourse analysis, Women Narrative 


\section{Decoding the Undecoded: Sexist Ideology \\ in Sherry Argov's Why Men Love Bitches?}

Marwa Abd El Azim

\section{Introduction}

\section{Sexism}

Sexism is defined as "the practices whereby someone foregrounds gender when it is not the most salient feature". (Mills, 2008:1). Language is the tool through which bias is achieved against women. It is similar to other discriminatory forms like racism. It is originated from authoritative societal forces, wider institutionalized inequalities of power and conflict over who has rights to certain positions and resources. This indicates that the society has the upper hand in influencing the emergence of prejudice against women. According to Mills, there is a continuous ongoing conflict between men and women. (Mills, 2008:1).

Sexism and sexist language have been a controversial topic since 1960s among feminist circles. It has been "so problematic" as a term. Previous studies have traced the use of sexist language in different disciplines. Many studies regard sexism as being deliberate not an outcome of individual differences. Research by the feminist Lakoff (1975) and Spender (1980), investigated the discrimination in language items between men and women. In addition, in their research, they discussed the issue of power and who deserves the right to get certain jobs and place in society. Cameron (1995) with other feminists introduced the notion of language reform and linguistic discrimination.
Mills presents a model of analysis to detect sexism in which she goes beyond investigating sexism at the level of sentence to extend it to the level of discourse. Sunderland (2004) also agrees with Mills' views concerning the importance of investigating sexist beliefs at the level of discourse. Mills (2008) believes that sexism affects men and women's lives. (p.35). This means that both genders are exposed to sexist bias.

It is worth mentioning that it is usually the confident women who are the ones exposed to sexist discrimination in public sphere. People tend to criticize them for their "sexuality" and "attractiveness" that "disqualify them" from maintaining a place in society. (40) A study by Walsh (2001) reports that a senior Labor party member has been disqualified from elections because of lacking certain beauty. The idea of using women's beauty as means to maintain prominence in society is considered an overt act of sexism. Mills (2008) states that it is the "public sphere" and media channels like "newspapers" that give certain stereotypical characteristics to women that categorize them. Those characteristics could "undermine" women both on the political and professional levels. One of the obvious stereotypical beliefs by the society is making fun of women drivers by telling jokes to weaken their confidence. Women drivers are overtly mocked and devalued. It is clearly stated that driving is mainly a male job not suitable for women that are received as being inadequate to 
drive compared to males. Mills argues that people are inclined to use specific "lexical choices" that "signal their views" about women. (p. 41). She distinguishes between two types of sexism-overt and covert.

Overt or direct sexism is the type of usage which can be straightforwardly identified through the use of linguistic markers, or through the analysis of presupposition, which Historically been associated with the expression of discriminatory opinions about women, which signals to hearers that women are seen as an inferior group in relation to males. (Mills, 2008, p. 11)

Thus, overt sexism is directly stated while covert sexism is interpreted from the meaning of utterances.

\subsection{Previous Studies}

The idea of examining the use of discriminating and sexist language has been widely investigated by many linguists. Several studies refer to English language in particular as being biased. Cameron (1998) is one of the feminists who concluded that English is a sexist language. Xialolan Lei (2006) argues that the English language is favoring men over women. But other studies on sexism in different languages reveal that sexism occurs in all languages and cultures too. Balraj (2012) examines the use of sexist terms in Malaysian lyrics to degrade women. Another study by Ikaria- Maina (2015): investigates sexism in Gikuyu language in Kenya. It reaches a conclusion that Gikuyu language is sexist. It gives examples from the morphology, syntax and imagery used in the language.

Ikaria- Maina (2015) states according to Atkinson (1993) that linguistic sexism is defined as "a wide range of verbal practices, including not only how women are labeled and referred to, but also how language strategies in mixed sex interaction may serve to silence or depreciate women as interactants" (p. 233).This implies that language can be used as a tool to devalue and downgrade the status of women in some societies.

A study by Demberg (2014) investigates linguistic sexism in online British newspapers. It uses Mills (1995) feminist stylistics mode of analysis to detect sexism on the word and discourse levels. The study examines 162 articles from the Daily Mail and concludes that linguistic sexism do exist in newspaper language. Another study by Darweesh and Abdullah (2016) examines Donald Trump's sexist ideology by using critical discourse analysis and Mills' (2008) mode of analysis. It finds out that Trump uses sexist language when expressing his opinions on women. Another recent research traces sexism in T.V. Drama by Nayef (2016). It applies feminist CDA in detecting the negative language used in addressing women in Al-Kabeer Awi sitcom in Egypt.

An earlier study by Jones (2010) on Sherry Argov's book "why men love bitches?" analyzed it from a feminist perspective and feminist criticism. It introduces the term "consciousness raising" employed by Campbell (2005) and relies on gaining knowledge from shared personal experiences of women to gain and create awareness about different issues like abortion. (Jones, 2010: p 10). According to Campbell (2005), consciousness raising leads to the risking of the self. She named the genre of feminist criticism "women's liberation rhetoric". (Jones, 2010: P. 8)

\subsection{Types of Overt Sexism:}

Mills lists different types of overt sexism that include generic pronouns, nouns, terms of address, affixes and word- 
endings, insult terms for women, semantic derogation, first names and titles, process and transitivity and finally proverbs. (Mills, 2008, pp 47, 70). For the purpose of this study, the focus is mainly on semantic derogation and proverbs.

\subsubsection{Semantic derogation.}

A great number of research has examined the terms associated with women and categorized them as being pejorative. According to Schultz (1990, p. 136), semantic derogation of women is shown especially in words that refer to those who have work authority. Theorists in gender and language studies claim that insult terms targeting women are exceeding men's terms. An example presented by Schultz proposes that calling a man by an old woman or a girl is an act of insult. It means that this person is weak. Mills presents examples of professions and activities of women that are mocked by some newspapers and magazines. For example, a magazine entitled "The Joy of Sexism" makes fun of women drivers and presents humorous reports on women drivers' inability to drive correctly due to their gender as women. Another example of sexism is in a UK radio program that insults female listeners with terms like "stupid cow" and "daft slapper". It also makes fun of women football players and sports that women play and are considered "stupid games". (Mills, 2008: p.12). An example of indirect sexism in British newspapers is in the Guardian newspaper that mocks the British foreign secretary Margaret Beckett. The newspaper keeps associating her with trivial concerns like enjoying caravan holidays to undermine her ability to fit in her profession.

Hellinger and Bussmann (2001) also criticize the use of certain words to degrade the status of female professions compared to men. The idea of referring to women in terms of their physical attributes only has been initiated by Schultz (1990). She believes that men are prejudiced against women through the use of pejorative terms. (Schultz, 1990, as cited in Mills, 2008:61)

\subsubsection{Proverbs:}

A proverb may carry sexist meaning. It is used in different cultures to deliver a certain message shortly and briefly. Throughout history, proverbs were used to refer to women in a biased way. They reflect social attitudes and beliefs. Some proverbs are humorous and funny, while others refer to women's body shape. An example of proverbs in English is the saying that goes "a woman's tongue cracks bones". In this proverb, women's tongue is mocked and presented in a funny way. It implies that women's talk can be so harsh like a hammer or any tool that is used to break bones. This proverb is linguistically sexist and humiliates the image of women.

\subsection{Types of Covert Sexism:}

Mills (2008) considers humor to be the first type of indirect sexism. To illustrate, "humorous utterances will presuppose that men and women are different and exaggerate that supposed difference." (p. 140). An example of sexism that appears humorous is in a situation when someone calls his wife "the wife" while introducing her to a friend. This way of introducing the wife is so sexist as there is no equivalent term as the husband in English. (p.141) Research goes on showing women as often been mocked by males in jokes (Crawford, Grey, 1994, Banks and Swift, 1987) as cited in Mills, (2008) p. 141)

The second type of indirect sexism is presupposition as stated by Mills (2008). According to Christie (2001), it is not easy to detect presupposition. It is chosen to hide sexism and to deny any responsibility on the part of the speaker. 
To illustrate the meaning of presupposition, as appears in a phrase asking women if they have finished gossiping, it presupposes that women are talkative by nature and enjoy gossiping in general compared to men. Mills, (2008), p.145. Another example of indirect sexism is through its use in the language of advertisements. Cameron (2006) traces the use of offensive sexist language of advertisements. He thinks that it is so difficult to investigate sexism on the level of presupposition. It is argued that complaining against indirect sexism is not taken seriously and is considered "an individual interpretation, which wouldn't be agreed on by majority of viewers." (Cameron, 2006)

Eckert and McConnell-Ginet (2003, p. 192) have referred to the implications of words used and the way it is believed to be based on sexual views. To clarify, when someone remarks that a woman is tall, it may imply that she will find difficulty in getting a suitable boyfriend.

Collocations are the third type of indirect sexism. In the media field, words become sexist when they are associated with negative connotations.

The word "mum" may not appear sexist unless it is used in a situation "where there is conflict over responsibility". Other words like divorcee, single mother, lone parent, working mother and career woman that are nonsexist may collocate or appear in negative and problematic contexts in the newspapers. For instance, the word lone parent is usually associated with drug issues that carry negative implication. (Mills, (2008) p.149)

Women magazines in particular are likely associating female celebrities with words like diet, weight loss or gossips. Romaine (2001) investigates the British
National Corpus for the collocations associated with the word spinster and finds out that most of them carry negative connotations. To exemplify, they include words like gossipy, nervy, over-made up, ineffective, jealous, love/sex-starved, frustrated, whey faced": (p.159)

Carroll and Kowitz (1994) find that certain adjectives collocate with male nouns and others with female -referent nouns. Adjectives like rich, brave, important and famous are associated to males while others like angry, beautiful and busy collocate with females. The study mentions that the word husband usually occurs in subject position compared to the word wife that appears in object position. The analysis of the place of those terms in a sentence shows the way men and women are characterized in that context. Romaine (2001, p.160) states that "collocations transmit cultural meanings and stereotypes which have built up over time." This means that collocations are not merely used; they are well chosen in association with other words based on traditional and cultural beliefs that emerge from their surrounding society.

\subsection{Covert (Indirect) Sexism and Media language}

Several studies argue that using sexist language is extensively used in certain newspapers, magazines, television advertisements, shows and programs. Usually in media context, humor and jokes are used to "deny the responsibility" for what is presented. (Mills, (2008), p.135). Another strategy that people use in-order not to appear sexist is to begin their speech with stating that they "don't want to be sexist or politically incorrect". (p.135). Many British newspapers tend to introduce women in weak situations compared to men who appear “in power". (p.137) 


\section{Feminist CDA}

Feminist CDA has been developed by Lazar (2005). It has been argued by Mills and Mullany (2011) that CDA is very suitable for feminist linguistic analysis. It fits in the analysis of media language and texts. It also helps in decoding the hidden sexist language.

\section{Methodology and Research Questions}

\subsection{Aim of the study}

This study aims to analyze the language used to address, describe and guide women. It hypothesizes that women are devalued and negatively represented. The language used is not as it seems to be to authorize women but rather to degrade and humiliate them.

It investigates the connotations of the lexical choices, the verbs, imperatives, presupposition, proverbs and rhetorical strategies that are utilized in the narrative to underpin the hidden ideology.

To investigate linguistic sexism in Sherry Argov's book, this study employs a qualitative method of analysis to examine the indirect elements of sexism as presented by Mills.

\subsection{Objectives}

The objective of the study is to explain the various elements of linguistic sexism found in the book "Why men love bitches"?

Those elements are summarized from the various sections of the book and are presented in the following part:

(a) Valuing women based on their appearance and beauty rather than intelligence or personality.

(b) Males are the norm. They are superiors compared to women

(c) Women are needy and dependent (d) Comparing women to inanimate objects

(e) Semantic derogation of women

(f) Women are negatively presented. They are boring, dumb and nagging

(g) Comparing women to animals and weak creatures (Mills, 2008)

To investigate the above mentioned elements, connotations of the lexical choices, collocations of words, verbs, imperatives and presupposition are examined, as introduced by Yule (1996) Other rhetorical strategies including metaphor and simile will also be analyzed.

\subsection{Research Questions}

1. How is linguistic sexism expressed in the book at the semantic, lexical and rhetorical levels?

2. How are women portrayed in the book?

3. What is the effect of the language used in the book on women?

4. How did the author manage to convince her women readers with her arguments?

\subsection{Data Analysis}

“Why Men Love Bitches' is written by Sherry Argov and published in 2000. Later on, it was translated into thirty languages and sold over 1 Million copies. The book consists of 271 pages. It contains 100 "attraction principles," for women to follow. The data collected include extracts from the various chapters of the book. The analysis includes the cover of the page and the implication of the font and colors used to affect the readers.

This study follows an eclectic approach in the analysis adopted from Mills' models of sexism (2008), Feminist Critical Discourse analysis and connotations of words and presupposition as introduced by Yule (1996). 
The tools of analysis that will be employed to trace Mills' models of sexism in the study are semantic strategies that include connotation of lexical choices, verbs, presupposition, proverbs and rhetorical strategies like metaphor and simile. In addition, some paralinguistic clues that appear in the book will be also analyzed.

\section{The Analysis}

\subsection{Paralinguistic clues in the cover of the book}

The Cover of the book includes Paralinguistic clues such as color, shape, size of letters or font that appear very significant. Those non-verbal modes of communication and semiotic signs appear for a reason. First of all, big bold letters are used on the cover of the book to attract the attention of readers. Also, it is highlighting and magnifying the word "BITCHES". In addition, there is a photo of a red Lip Stick that symbolizes feminine aspects.

The use of colors on the cover of the book may imply certain connotations and meanings. The Red Color signifies fire, passion and love. Black color connotes power. As for the background, it comes in white which is a neutral color.

\subsection{Connotation of the titles and sub- titles in each chapter}

Each chapter starts with a title and is followed by sub-titles that introduce each attraction principle.

\section{Example: (1)}

Why Men Love Bitches: From Doormat to Dream girl - A Woman's Guide to Holding Her Own in a Relationship.

In the above title, the author does not use the word "bitch" in its literal sense. On the contrary, she is using it ironically to imply a strong powerful and ideal woman that all women should strive to be like.

The woman I'm describing is kind yet strong. She has strength that is ever so Subtle. She doesn't give up her life, and she won't chase a man. She won't let a man think he has a100 percent hold on her. And she will stand up for herself when he steps over the line. (xiii)'

The message of the book as stated by Argov is "to empower women". Also, she calls ordinary women who are not that powerful as being a "Doormat' which is a powerless object. This is a very sexist term and a direct objectification. It is insulting and degrading women to the status of an object or thing that is so humiliating. A "Dream girl" or a "bitch" implies that the bitch is the powerful woman that everyman dreams of.

\section{Example: (2) Chapter One}

Title: "From Doormat to Dream girl"

Sub-Title: "Act like a prize and you will turn him into a believer".

In the above sentence, the verb "to act" is so sexist. It implies that women should act and not behave naturally in order to be liked by male figures.

\section{Example: (3) Chapter Three}

Title: The candy store

Sub-Title: How to make the most of your feminine and sexual powers

The title and subtitle are both carrying sexist language. Women are judged by their appearance only. It indicates that women's beauty is the merely the source of their power. It implies that women may lack intelligence or other assets that make them equal to men. Comparing women to a "candy store" is very pejorative. 


\section{Example:(4) Chapter Six}

\section{Title: "NAGGING No MORE"}

Sub-Title: "What to do when he takes you for granted and Nagging does not work"

Argov goes on giving instructions to her readers on how to get a man. She claims that women appear to be nagging for attention. This is a negative verb which implies that all women are irritating by nature.

\subsection{Lexical words with negative connotation.}

\section{Example (1)}

Everyone has known a "nice girl". She is the woman who will compensate, giving everything to a man she barely knows, without him having to invest much in the relationship. She is the woman who gives blindly because she wants so much for her attentions to be reciprocated. She is the woman who goes along with what she thinks her man will like or want because she wants to keep the relationship at all costs. Every woman, at some point, has been there. (p.2)

In the previous extract, the writer is describing a woman who seeks little attention from men and wants the relation to be going on as being a "nice girl". The word "nice girl" is used in a humorous way to imply the needy woman who degrades herself for the sake of male attention "Every woman" is a generalization that implies all women are that kind which is not true.

\section{Example: (2)}

It started when he was a kid. When he received a toy for Christmas that he didn't ask for, he played with for a whole five minutes. The toy he cherished was the one he bought with two months' allowance that sat on the top shelf in the toy store. He couldn't reach it but went in to look at it all the time. He got up every morning at the crack of the dawn to toss papers on a paper route to get that toy. It's the one toy he will always remember because he had to earn it (p.17)

The idea of referring to women as inanimate objects is clear in the above extract. Women are no more than possessions that a male figure will try to buy with his money to get. The word toy is a very sexist term used along the chapter to describe women.

\section{Example (3)}

"If you treat yourself as a valuable commodity, he will naturally put more stock in you." (p.35)

"It's verbal foreplay........ “ It's a sales pitch", (p.216)

In the above extract the repetition of the idea of treating women like a "commodity" waiting to be sold by men is clear. In this example, women are compared to a product that is exposed to selling which is so degrading to women status. It is so sexist and connotes that women have no feelings or identity. They just exist to satisfy men's needs. The woman, who behaves well, is the one to be valued by men with a high price. Again the idea of a bargain is repeated here in the above examples. The whole relation-ship is like a buy and sell relation- ship. Men are doing anything possible to buy the desired women. They try to appear gentle by opening the car door and using eloquent language to convince women to "throw- down in the bed room" (216). They keep telling women that they have 
got all the ideal traits they are looking for in a relation-ship. The relation-ship is like a "game plan" (216). Men are planning to get women through everything possible.

\section{Example: (4)}

"He'll never respect you as being able to hold your own unless you can stand on your own feet financially." (p.175)

When it comes to financial independence, the author advises women to be independent and earn their own living. Using the word "respect" in relation to financial independence is so sexist. Many women do not work and rely on their husbands without being disrespected.

\section{Example :( 5)}

"It is sexy to be able to banter because humor suggests you're an independent thinker". (p. 210)

In the above example, women are evaluated based on their ability to laugh not on their intelligence. This is a sexist example that degrades the level of women. If women can laugh it connotes that they are "independent thinkers".

“............ For example, he may make fun of the way you parked your car. This kind of joking makes him feel manly. A relaxed aura from a woman who can laugh at herself turns him on because he thinks she'll be entertaining and fun." (p. 211)

In the previous example, there is another evidence of the sexist language used by men to describe women. Women are invited to accept men who make fun of them when they park their car. That is not all, men feel so satisfied when women laugh at themselves too. This attracts men and make them "Turned on" and more appealing to women.

\subsection{Presupposition}

A presupposition is a semantic strategy that implies assumed and unstated things. It is embedded throughout the book in several sentences and phrases.

\section{Example: (1)}

"Never assume you are not attractive enough, and therefore you have to overcompensate or chase a man. Taste is subjective. One man's ugly is another man's beautiful". (p.16)

In this extract, the writer tends to advise women not to feel unattractive if not liked by men. She tells women not to count on men to give them credit for their worth. The semantic strategy of presupposition is used here. The implication is that women are only judged by their appearances. The use of the word "Taste" again is so degrading to women. The sentence "one man's ugly is another man's beautiful" is similar to the famous proverb "one man's meat is another man's poison". This shows the subtle style of the author of this book. She tends to use proverbs and phrases that are familiar to the reader's mind. Proverbs are brief and full of rhyme. In the above example, the eloquent sentence that resembles a proverb is used to make a comparison between the different types of men. This is done on the part of the writer to sound more convincing and prove her point.

\section{Example: (2)}

Another example of presupposition in the book is the one below. In this sentence, it is indirectly inferred that women are so needy and tend to "chase men". It is so humiliating and sexist sentence. Later on the writer overtly states that she refers to women who chase men till they lose them. 
Example: (1) If you don't make him feel locked down, he will come your way" Think of him as a frightened stray dog. Eventually, he'll drop his guard And come around. But if you charge at him or try to corner him, he'll bolt. (p.46)

In the previous example, the image is a simile associating women to a guard while men to a " "stray frightened dog". The image with the verbs used carries negative connotations against women. Men are compared to a frightened dog that is being terrified by women. This example resembles the poem "Follow a shadow. It still flies you". It is written by Ben Jonson who also advices men to ignore women altogether and they will run back after men. In the above example, Argov is also advising women to stop following men. She is mirroring Ben Jonson's advice to men, using a different wording that is familiar to the reader. So both writers believe that men shouldn't follow women and women shouldn't follow men. Women don't have the right to question their men about the relationship. They should stay passive and never argue with men in order not to lose them. This example is so humiliating to women. Men have the upper hand all the time and women should never complain nor disagree. Argov tries to prove her point in a very eloquent style that appeals to the reader's subconscious. Her ideas are taken for granted and will be accepted by the reader as they are programmed in their mind as part of their folklore and culture.

\subsection{Imperatives}

The writer gives the readers direct instructions and steps to follow to gain success in their relationship with men. She introduces those pieces of advice in the form of imperative verbs. This implies that 
sexist social belief that males are the norm while women are just depending on them.

\section{Example: (3)}

"Do things........

"Give kisses......

"Smile a lot.......

"Flirt in moderation....

"Compliment him....

"Show that you are

affectionate and loving....

"Don't you ever tell him.....

"Be affectionate in public." (pp.65, 66, 67)

“Don’t talk on the phone (p.112)

whenever you think of him, stop.” (p.225)

Throughout the book, linguistic sexism is depicted in the way Argov guides women not to behave normally when dealing with men. She claims that if women are naturally expressing themselves they appear needy. To illustrate, in some chapters she asks a woman not to tell her man "I miss you". (p. 40). She advices women not to show their emotions to men or express their love.

\section{Example:(2)}

......when you act too much like Tarzan, he feels too much like Jane. Don't even kill a bug when he's around. Don't change a tire. In fact, don't even change a light bulb......(p.78)

The writer in the previous extract asks women to appear needy and naïve to gain men's love. She advises women to give credit and appreciates anything men do in order for the relation to succeed. This is so demeaning to women. It emphasizes the
.........Use the word best, and you 'll always have his full attention.” (p.79)

"Whenever he does something handy around the house like putting up a shelf, praise him." (p.80)

Again, women are asked to praise men for whatever they do just to "gain their attention". Women should give words of appreciation for men even if they have done trivial things. This is another example of linguistic sexism against women.

\subsection{Use of Proverbs}

"Wearing her heart on her sleeve almost all the time." (p.93)

"But novelty wears off very quickly" (p.93)

"The candle that burns twice as bright burns half as long." (p.108)

“A man's heart comes from his stomach". (p. 204)

"........, they are green with envy." (p.224)

Proverbs are employed by the writer to deliver certain brief messages addressing women in particular. Some of them carry funny words to sugar-coat the hidden meaning. They include reference to women body parts. Proverbs represent stereotypical beliefs of each society.

They are sexist when they depict the image of women negatively. The writer employs proverbs to give credibility to her ideas and to sound more convincing. 
"Like a seal, or a sea otter at sea world........... and the seal isn't doing the tricks to impress the audience. He's doing the tricks to get a salmon.....................if he wants to get the treat, he has to do the trick."(pp. 216, 217)

In the previous extract, men are compared to a seal that appears in the circus and women to the salmon which is the gain they receive after they finish their trick. Men are shown as being smarter than women. They are exerting an effort and planning to gain their women. This is a very discriminating example that compares women to food that is edible by men.

\section{Example: (4) Simile}

"I wonder what she's really like. She can't possibly be that nice. Like a low-interest rate Credit that's only good for the first month, he'll start to feel he's getting the promo package. Not the real deal. (p.237)

According to Argov, women who show kindness in their relationship are viewed as weak. They are viewed all the time as an investment by men. If they are not giving the expected gain, they are disregarded by men. Sexism is so clear when comparing women to objects like "a low-interest-rate credit" in a very demeaning way. They are treated like products that have no feelings or mind. This example adds to the so many others that address women in a very undignified way that lowers her standard compared to men.

teenager who's been given a curfew by mama". ( pp.40,41)

In the above example, men are compared to teenagers while women on the other hand appear like their mothers who punish them for their bad attitude.

Example: (3) Simile

\section{Example: (5) Metaphor}

"Men are hunters, and like any hunting animal, they are more intrigued by conquering prey when it resists the predator." (p.44) 
In the above example, the metaphor is degrading the image of women. They are compared to a prey while men are the strong hunters who will hunt them. Thus, it states indirectly that men are having the upper hands over women. They are compared to hunters who choose only women that attract their attention. This metaphor emphasizes the idea of superior/ inferior relationship which is so sexist.

\subsubsection{Food imagery}

Food is a passive substance waiting to be eaten. The writer keeps comparing women to a peach and sometimes to a candy store which are very degrading images.

"A bitch is nice.

She is sweet as a Georgia peach" (p.19)

"Don't give up the candy store at once" (p.54)

\subsubsection{Plant imagery}

One of the obvious images that appear among the attraction principles given to guide the readers is the plant imagery. The writer resorts to highlight the contrast between women and male figures through the use of simile. In this example, men are compared to a plant that if given too much attention by women will "be Killed" like overwatering a plant. Again, the image portrays women negatively as lacking pride. It is one of the several images in the book which implies that women are chasing men all the time. Women exert an effort to win men's hearts while men are suffocated from their excessive attention.

"His psyche is like a plant. It needs water but also air to breathe. To give a man too much reassurance too soon is the same as overwatering a plant. It Kills it." (p.19)

\subsection{Collocations}

Men also are described with words that show them stronger than women. They are hunters, fighters, investors, winners and gainers. Women are the prey that they seek hunting.

Example: (1) "Another example is when he goes on the hunting trip......He sleeps in a grungy sleeping bag and gets chewed up by mosquitoes. He eats food that prison inmates wouldn't touch. For what? The hunt (p.27)

So in the above example, men appear so strong and patient. They fear nothing in return for their hunting. They are active while women are the passive ones. In the book they are compared to strong historical characters. They are "like Captin Kirk and Christoper Columbus “. (p. 58).

Example:(2) “Men like things that are difficult. They like to drive stick-shift automobiles. They like to jump out of airplanes, and they like to climb mountains. They like to do the impossible." (p.41)

Example: (3) "Men have big egos and they need to have them stoked. This is what the "dumb fox" does. In small ways, she makes him feel like he is the King Kong of her world........"(p.81)

In the previous example men appear as being the strong ones all the time. They are physically powerful. They are capable of doing "the impossible' which is glorifying the image of men. Women are asked to treat them like "King Kong" that is the symbol of power. 


\section{Example: (4)}

Continuing the image that depicts the strength of men, they are similar to lion trainers who tame women. It is a very demeaning image of women who are compared to a wild animal that can be controlled by men. Once more, sexist language is subtly used by the writer. It implies that the relationship between them is not equal. Men exert an effort to be able to deal and control them.

"When it comes to a commitment or a relationship with most women, men feel like lion trainers, it's as though they have to use a chair to get the lions to back away." (p. 241)

\subsection{The use of Quotations:}

Each chapter begins with a different title that summarizes briefly its content and at the bottom of the page the author provides a quotation by a well-known figure whether a man or a woman. It may be intended by the author to give credibility to her argument. It is a way to convince women readers that she is guiding and empowering them. Some examples of quotations by Famous figures appear below:

"Sex appeal is $50 \%$ what you've got, and 50\% what people think you've got."

Sophia Loren

"Happiness? A good cigar, a good meal, and a good woman. It depends on how

much happiness you can handle.” George Burns

"Elegance does not consist of putting on a new dress." Coco Chanel

"Well done is better than well said." Ben Franklin
"Sex is like a small business Y'a gotta watch over it" MAE West

It is clear that all the previous quotations are said by the famous figures like the well-known actress, Sophia Loren, to encourage women to follow her in her footsteps. This is a well-known rhetorical device used by writers to affect their readers.

\subsection{Real -life Examples and Names}

Another convincing strategy that is depicted is the use of specific examples by the writer to verify her logic. She tends to even mention the names of the women whom she narrates their stories to clarify her point. Moreover, to assert her points, Argov cites examples taken from letters sent to her by women seeking advice. Once more, the writer is giving credibility to herself by quoting real life examples and situations. She wants to gain the confidence of her readers by all possible means.

Example: (1) “A friend of mine named Crystal was in this exact situation and handled it perfectly. A man named Brett called her on a Saturday night." (p.34)

\section{Conclusion}

Language is a powerful tool. It is not neutral at all. It is not as it seems to be "empowering woman" as mentioned earlier by the writer. At the first glance, women could be easily fooled by the so many words of guidance that appear to be for the wellbeing of women readers. After a profound second reading and applying tools of linguistics, the hidden ideology behind this book is clarified and decoded. Argov actually deceives women especially those who had just a quick look at the title. Through the analysis of the lexical choices, presupposition, verbs and 
rhetorical devices, answers to research questions are as follows: The lexical choices and imagery used by the writer to describe women are not neutral at all. On the contrary, they are derogatory terms that carry negative connotations. Women appear as needy and hopeless. All the time, they exert an effort to win men's attention. They are compared to dolls, products or things. Also, imagery of weak animals like ostrich and moose are given to women to degrade their status all the time. Other examples of food imagery and fruits are used throughout the book to compare women to edible things.

This study shows that writers can intentionally choose words that carry covert meanings to impact readers' perception. Women should pay more attention to word choices rather than simply accepting what is written as it is. For writers to promote their books, they tend to Sugar-coat their writing by claiming that they write to help and empower women. Argov uses quotations by famous people, and gives several examples from real life stories to defend her argument. Women should adapt all the time to fit in men's world. If a woman wants to win a man's heart, she should exert an effort and follow Argov's tactics. She also uses collocations and proverbs from culture to persuade women with her ideas through appealing to her emotions. Moreover, she uses intertextuality as a literary device to persuade her readers.
This appears FOR example when she mirrors Benjonson's claim about women in his poem "The shadow". She employs the three classical categorizations of rhetoric developed by Aristotle, Ethos (ethical proof), pathos (emotional proof) and Logos (logical proof) to achieve the ideology of convincing her readers with her attraction principles. Persuasion is subtly employed to attract readers to buy the book. A thorough reading can reveal the truth behind this book.

In fact, this book is not value free, it is written in a very intelligent way to attract readers and sell more copies. Through feminist critical discourse analysis, the hidden meanings are revealed. Also, a quick review of the paralinguistic tools including the layout of the book, the font and colors used, it is clear that they play an important role in interpreting the ideological hypothesis behind this book. They act as attraction tools for readers to go and buy the book. The study is restricted to the analysis of some extracts that were randomly chosen from the chapters of the book. This is done to give credibility to the results and findings of the analysis. For, further study in the future, it is suggested for researchers' to apply a different analytical framework to find out more of the hidden secrets of this bestselling book worldwide. 


\section{References}

Argov, Sherry (2000). Why Men Love Bitches: From Doormat to Dreamgirl - A Woman's Guide to Holding Her Own in a Relationship. Avon, MA: Adams Media

Balraj, B. (2012). A case study on selected terms used to describe women in selected Malaysian Hip Hop Lyrics", European Journal of Business and Social Sciences. 1(6), 2-14.

Cameroon, D. (1985). Feminism and linguistic theory. Basingstoke: Macmillan

Cameron, D. (ed.) (1998). The Feminist Critique of Language: A Reader. 2nd ed. London: Routledge.

Cameron. D. (2006). Language and Social Politics. London: Routledge.

Campbell, K. K. (1973). The rhetoric of women's liberation: An oxymoron. Quarterly Journal of Speech, 59(1), 74-86

Christie, C. (2001). Gender and Language: Towards a Feminist Pragmatics. Edinburgh: Edinburgh University press

Darweesh, D \& Abdullah, N. (2016). “A Critical Discourse Analysis of Donald Trump's Sexist Ideology." Journal f Education and Practice, 7(30), 87-95.

Demberg, R. (2014). "Linguistic Sexism". A study of sexist language in a British online newspaper", BA thesis, Linne universitetet, Sweden.

Eckert, P. \& McConnell-Ginet, S. (2003). Language and Gender, Cambridge: Cambridge University Press.

Graddol, D. \& Swann, J. (1996). Gender Voices. Oxford: Blackwell.

Halmari, H., \& Virtanen, T. (2005). Persuasion Across Genres. Amsterdam: John Benjamins

Hudson, R. A. (1989). Sociolinguistics. Cambridge: Cambridge University Press.

Hellinger, M. \& Bussmann, H. (eds.) (2001). Gender Across Languages: The Linguistic Representation of Women and Men, vol. I, Amsterdam and Philadelphia, John Benjamins.

Ikaria-Maina, N. (2015). Linguistic Sexism: A Case of Gikuyu Language Discourse in Kenya. International Journal of Science and Research (IJSR), 4(2). 232-37

Jones, L. S. (2010). Why Men Love Bitches: A Feminist Perspective. California Polytechnic University, San Luis Obispo

Jackson, S. \& S. Scott (ed.) (2002). Gender: A Reader. London: Routledge.

Lyons, J. (1970). Linguistic Semantics: An Introduction, Foreign Language Teaching and Research. Cambridge: Cambridge University Press.

Lakoff, R (1975). Language and woman's place. New York: Harper \&Row. 
Lazar, M. (Ed.) (2005). Feminist critical discourse analysis: Gender, power and Ideology in discourse. London, Palgrave Macmillan.

Mills, S. (1995). Feminist Stylistics. London: Routledge.

Mills, S. (2008). Language and sexism. Cambridge: Cambridge University Press.

Mills, S. \& Mullany, L. (2011). Language, gender and feminism: Theory, methodology and practice. London: Taylor \& Francis.

Nayef, H. (2016). "Linguistic Sexism in T.V. Drama: A Linguistic Analysis of Verbal Violence against Women in the Egyptian Sitcom Al-Kabeer Awai. International Journal of Linguistics and Communications, 4(1), 84-103.

Pauwels, A. (2003). Linguistic Sexism and Feminist Linguistic Activism. In Holmes, J. \&Meyerhoff, M. (eds.). The Handbook of Language and Gender. (pp. 550-570). Oxford: Blackwell.

Romaine, S. (2001). 'A corpus-based view of gender in British and American English', in Hellinger, M. and Bussmann, H. (eds.). Gender Across Languages: The Linguistic Representation of Women and Men, vol. I, Amsterdam and Philadelphia, John Benjamins. ( pp. 154-75).

Schultz, M. (1990)."The semantic derogation of women', in Cameron, D. (ed.) The Feminist Critique of Language: A Reader. (pp. 134-48). London, Routledge.

Spender, D. (1980). Extracts From Man Made Language. In: Cameron, D. (ed.). (1998). The Feminist Critique of Language: a Reader. 2nd (ed.) London: Routledge. (pp 9399).

Sunderland, J. (2004). Gendered Discourse. London, Palgrave Macmillian.

Walsh, C. (2001). Gender and Discourse: Language and Power in Politics, the Church and Organizations, Harlow, Longman/Pearson.

Xiaolan, Lei (2006). "Sexism in language". Journal of language and linguistics, 5(1). 87-94.

Yule, G. (1996). Pragmatics. Cambridge: Cambridge University Press. 